Paideusis

\title{
Placing Education: The School as Architectural Space
}

\section{Neil Gislason}

Volume 16, Number 3, 2007

URI: https://id.erudit.org/iderudit/1072485ar

DOI: https://doi.org/10.7202/1072485ar

See table of contents

Publisher(s)

Canadian Philosophy of Education Society

\section{ISSN}

0838-4517 (print)

1916-0348 (digital)

Explore this journal

Cite this article

Gislason, N. (2007). Placing Education: The School as Architectural Space. Paideusis, 16(3), 5-14. https://doi.org/10.7202/1072485ar

\section{Article abstract}

School architecture is a vital part of the learning environment: An educational facility should actively support learning processes which are grounded on an applied, multidisciplinary curriculum. This paper argues, accordingly, that a school should provide flexible educative spaces which properly enable multiple forms of teaching and learning. Support for this thesis is drawn from spatial theory, John Dewey's writing on educative spaces, architectural writing and ecological design theory. It is finally posited that we need move beyond certain industrial-era assumptions about learning, in order to lay the conceptual foundation for a dynamic notion of architecture for education.
This document is protected by copyright law. Use of the services of Érudit (including reproduction) is subject to its terms and conditions, which can be viewed online.

https://apropos.erudit.org/en/users/policy-on-use/ 
Paideusis, Volume 16 (2007), No. 3, pp. 5-14

\title{
Placing Education: The School as Architectural Space
}

\author{
NEIL GISLASON \\ Ontario Institute for Studies in Education of the University of Toronto, Canada
}

School architecture is a vital part of the learning environment: an educational facility should actively support learning processes which are grounded on an applied, multidisciplinary curriculum. This paper argues, accordingly, that a school should provide flexible educative spaces which properly enable multiple forms of teaching and learning. Support for this thesis is drawn from spatial theory, John Dewey's writing on educative spaces, architectural writing, and ecological design theory. It is finally posited that we need to move beyond certain industrial-era assumptions about learning, in order to lay the conceptual foundation for a dynamic notion of architecture for education.

\section{Introduction and Overview}

Academic writing on learning environments has split into two discursive strands over the last decade. On the one hand, learning environment research focuses on how student performance is affected by social factors like staff and student relations, socio-economic status, and school culture (Johnson \& Stevens, 2006). School facilities research meanwhile studies academic outcomes relative to the structural quality of schools (e.g., Doppelt, 2006; Lackney, 1996; National Research Council, 2006; Schneider, 2002; Tanner, 2000). These two areas of inquiry do not overlap in practice. As a result, environmental research on $\mathrm{K}-12$ schools has bifurcated. One camp is centered on the psychosocial dynamics of the classroom, and the other is geared towards educational facilities.

This paper asserts, in Section (1), that it is a mistake to fully bracket the psychosocial dynamics of a classroom and set them apart from the school's built form. Schools, like other constructed spaces, are built environments that convey potent messages about how to think and act within a particular milieu (Markus, 1993). The social patterning and learning processes which take place within a school are therefore intimately joined to their material context. John Dewey, a keen observer of educational spaces, touches on this interconnection in Democracy and Education (1916/2005):

Where schools are equipped with laboratories, shops, and gardens, where dramatizations, plays, and games are freely used, opportunities exist for reproducing situations of life, and for acquiring and applying information and ideas .... Ideas are not segregated, they do not form an isolated island. Information is vitalized by its function; by the place it occupies in direction of action. (p. 96)

(C) Copyright 2007. The author, Neil Gislason, assigns to Paideusis the right of first publication and educational and non-profit institutions a non-exclusive license to use this document for personal use and in courses of instruction provided that the article is used in full and this copyright statement is reproduced. Any other usage is probibited without the express permission of the author. 
Learning takes concrete shape, in other words, within its social-material surround. A school site should therefore support dynamic learning processes, both materially and socially; but this does not necessarily happen in every setting. For this reason, it is important to consider how a given school space functions as a pedagogical instrument. Places can serve as effective teachers, but they can also impede the educative process (in Dewey's sense of "vitalizing" information) if they are inadequate.

Sections (2) and (3) examine Dewey's views on educative space, to explore what is theoretically entailed by an effective school environment. Two essential principles emerge in this respect. First, the school milieu should serve as an extension of pedagogical practice in a physical sense, in that the right materials (toys, books, scientific apparatus, etc.) should be at hand. A school, furthermore, should not be divorced from normal social space. If it is, it becomes a self-enclosed environment - a "divided world," in Dewey's phrasing (1938/1997, p. 44). Such an environment uproots learning from the social context which is the proper origin and end of the learning process.

Finally, Section (4) posits that we are entangled within an industrial-era school design paradigm. It is suggested that ecological design theory, which is consonant with Dewey's theory of educative space, offers a way to move beyond the present conceptual impasse in school design discourse.

\section{Architecture as Pedagogy: A Theoretical Framework}

The idea that architecture, or built form generally, somehow teaches lessons about behaviour may initially seem illogical. Buildings do not possess the characteristics usually required of a teacher, after all. They do not speak in any literal sense, nor do they gesture, think, dialogue, and so forth. They are for all practical purposes silent, immobile, and unreflective. They are, in this way, more like a rock than a person, and are without particular meaning.

Yet, buildings do communicate ideas, form perceptions, and guide actions, as might a teacher. Buildings are indeed loaded with messages regarding how one should talk, behave, interact, and so on (Peponis \& Wineman, 2002, pp. 271-91). In a typical two-storey home, for example, the living room serves as a semi-public space close to street access, and is broadly associated with outwardly social behaviour. The master bedroom meanwhile acts as a largely private space enfolded within the home's interior, and is associated with intimacy: it is the near opposite of the living room. A building is thus more than a merely physical structure, as it is also packed with visual and spatial messages about how to feel and act in a certain location. There is not a strict correspondence, though, between environment and behaviour. Built spaces are inevitably assigned different interpretations over time, just as their uses shift to one degree or another (e.g., a Victorian factory might be transformed into a residential loft). As Aldo Rossi puts it, there is architecture, but there is also "the life of the works themselves," which changes as their social and historical context alters (1984, p. 116).

While there is variability in how people relate to a space over time, there is nonetheless an overall continuity regarding the cultural norms which underpin the social dynamics of a place at a particular moment. Donald Preziosi notes in this respect that

it would seem that spatial behavior and built environments manifest a certain semi-autonomous relationship - much less rigidly determined than that between the behaviors of certain social insects and their hives or nests - and yet somehow not . . completely arbitrary, being to some extent grounded in the routines of convention which differ from one society to another. (1979, p.13)

Built environments do not express anything, in other words, except insofar as they serve as adjuncts to a wider social purpose which is historically and culturally defined. Built spaces in this capacity offer a kind of signifying field for human activity, helping to give it an immediate and grounded direction. 
Human activity does not merely take shape at a certain socio-historical point, then, but it also takes place within the specific material context by which it is informed.

The built environment, I would argue, 'teaches' perception and behaviour on two basic levels: social and phenomenological. We have glanced, so far, at the social aspect of built form, which is constituted by the communication of cultural and behavioural norms through spatial and visual conventions. These norms, it should be noted, are rarely if ever value-neutral. Anthony Giddens observes in this regard that there is tension within many spaces (such as an office) between individual agency on the one hand, and managerial or disciplinary power on the other (1984, p. 157). There is often an asymmetry, therefore, in the power relations that are reified via the built environment. In an educational context, it has been suggested that the configuration of a classroom reinforces certain power dynamics between teachers and students. J. W. Getzels (1974) proposes that a rectangular layout strongly favours a teacher-centered pedagogy, for example: the student's attention is firmly fixed on an authority figure - the teacher - who occupies a central position of command, in both a spatial and a pedagogical sense. Paulo Friere (1970/2000) has famously described this one-sided educational paradigm as the banking concept, whereby "students are not called upon to know, but to memorize the contents narrated by the teacher" (p. 80).

If the social significance of a place largely derives from its capacity to buttress various social and institutional dynamics, then its phenomenological meaning is centered on how individuals personally negotiate a site. It should be noted here that social and individual should not be treated as antithetical terms. Cultural norms may condition one's private experience as an outside power, but culture is also performed through individual actions. The social and the individual are thus two sides of one fabric. Giddens (1984) suggests, along these lines, that while individuals do not create social systems, they nonetheless "reproduce or transform them, remaking what is already made in the continuity of praxis" (p. 171). Individuals may be influenced by a context which is largely beyond their control, then, but their actions are finally an extension of personal agency. For this reason, a place is not merely a socially and historically conditioned field that informs action; it is also a space in which personal meanings are accumulated, developed, and expressed as a matter of individual agency (Robinson, 2003, pp. 143-144). A place does not only reify cultural or institutional norms, therefore, it also helps ground personal meanings within a durable, material framework. This gathering and construction of individual meanings within a site ultimately defines one's experience of a place - and this individual experience constitutes the phenomenological dimension of a place.

Martin Heidegger (1971) offers a good illustration of how the built environment functions on a phenomenological level. In the essay, Building, dwelling, thinking, he describes how a bridge crossing a stream perceptually structures the landscape. Heidegger explains that

[the bridge] does not connect banks that are already there. The banks emerge as banks only as the bridge crosses the stream. The bridge designedly causes them to lie across from each other. One side is set off against the other by the bridge. Nor do the banks stretch along the stream as indifferent border strips of the dry land. With the banks, the bridge brings to the stream the . . . expanse of the landscape lying behind them. It brings stream and bank and land into each other's neighborhood. (p. 152)

In Heidegger's account, the bridge introduces difference into a previously undifferentiated landscape. The bridge marks the difference between the banks, for example, by making them "emerge as banks" on opposing sides. Bridging therefore does not only connect things; it also "set[s] off" things from one another. The landscape, the banks, and the stream are in this fashion all distinguished from each other, as discrete parts of a whole. What makes these elements insistently particular - the reason that they are necessarily different from one another - is that the act of bridging subjects them to human designs: the bridge works "designedly," as an expression of a differentiating intent. There is no "other side," that is, unless there is an intention to get there. There are no banks, unless one is looking for a place upon 
which to set the bridge. There is no landscape, unless one glances deliberately beyond the banks. All of the differences and contiguities that Heidegger draws to our attention are thus in fact the percepts of a mind which is purposively conjoining aspects of the built environment, and thereby forming a coherent place-experience. Heidegger elsewhere in the essay calls this kind of activity "dwelling" (p. 157). Human dwelling is nothing other than the process whereby we make sense of our world within the context of a place. A place enables dwelling in that it articulates a certain intention or purpose through built form, while the act of dwelling is precisely one's construction of meaning in a place.

In all, Building, dwelling, thinking suggests that if consciousness (dwelling) enables the continuity of experience over time, then places (dwellings) frame the construction of meaning within space. The 'time' of consciousness and the 'space' of place act together to constitute our phenomenological "patterning [of] the world" (Merleau-Ponty, 1962/1981, p. 447).

It is fairly easy to reconcile the social and phenomenological facets of place, at least conceptually. On a social level, as I have suggested, a place serves to situate people within a material context which communicates cultural values, and which directs behaviour and perception in accordance with those values. On a phenomenological plane, meanwhile, a place orientates individual perception towards a given purpose or intention, and generally provides a means of its fulfillment (Heidegger's bridge signals an intention to cross the river, for instance, and supplies a means of doing so). Situation and orientation have at least one important thing in common: they are fundamental to our capacity to make meaning of, and in, the world. We must be both situated and orientated, if we are to dwell meaningfully; and we must build in order to dwell.

\section{Theorizing School Architecture: Spatial Theory and Dewey's Concept of "the School"}

Dewey's writing reflects a sharp awareness of the role of the environment in shaping and directing experience, and he outlines principles akin to those of situation and orientation. His sensitivity to the orientating role of the educative milieu is something we have already glimpsed, in his observations on the formative relationship between learners and the pedagogical environment. Dewey's notion of "the environment," one should remember, is drawn broadly. It encompasses, for example,

persons with whom [the learner] is talking about some topic or event, the subject talked about being also part of the situation; or the toys with which he is playing; the book he is reading (in which the environing conditions at the time may be England or ancient Greece or an imaginary region); or the materials of an experiment he is performing. (1938/1997, pp. 43-44)

Any object, idea, or activity which helps channel the student's experience is folded, in this way, into Dewey's concept of the environment. Significantly, immaterial phenomena (e.g., the imaginary worlds of books) and social activities (dialogue and play) co-exist in this list with physical objects (experimental materials): the material surround and experience mutually support, and indeed penetrate, one another. Dewey's view of the environment is in this regard essentially phenomenological, in its emphasis on the experience of learning within a perceptually engaging milieu.

The belief that we need to provide a place for experience within the educative setting is a heavily recurrent theme in Dewey's writing. Dewey expresses this principle in his comments on the practice of teaching, for instance. He suggests that the primary responsibility of an educator is to know how to "utilize the surroundings, physical and social" (p. 40), in order to maximize access to learning experiences which are meaningfully grounded in "everyday social applications" (p. 80). Now, Dewey's concept of the school takes a radical turn at this point, because his insistence that education should relate directly to the wider social sphere requires that learning must be situated partly outside of the traditional confines of a school's walls. He writes: 
The [traditional] school environment of desks, blackboards, a small school yard, was supposed to suffice. There was no demand that the teacher should become intimately acquainted with the conditions of the local community, physical, historical, economic, occupational, etc., in order to utilize them as educational resources. (p. 40)

The learning environment is conceived in this manner as something which cannot be strictly confined to the boundaries of a self-contained school. On the contrary, Dewey believes that the boundary between the school and its encompassing social context must be levelled, at least conceptually, so that what happens behind school walls couples with what happens outside of them. This close correlation ensures that the learning process is authentic, because it links education to real-world patterns of experience, rather than to the relatively contrived and self-enclosed methods of traditional schooling.

In sum, Dewey asserts that the school environment should relate in form and in function to the wider social surround; a school should not be paradigmatically different, therefore, from normal social space. If it is, it will be a "divided world," "whose parts and aspects do not hang together" because it is environmentally divorced from its proper context - that is, separated from its fundamental situation (p. 44). Such a school is disorienting, furthermore, in that its materials and general environment spiral students' perceptions away from the enveloping space outside. It is not a good dwelling-place, in Heidegger's sense, because it is really a fragmented, and perceptually fragmenting, version of "the actual conditions of life" (p. 48). An effective school milieu, on the contrary, supports learning which is consistent with real-world conditions in both subject matter and method: it serves as an embryonic version of actual social space, and stimulates "new ways of observation and judgment [that] will expand the area of further experience" (p. 75). Such ongoing stimulation finally aims to equip students with a lasting ability to relate to increasingly broad environmental contexts, and to derive ever-deeper meaning from them: "Life-space and life-durations are expanded. The environment, the world of experience, constantly grows larger and, so to speak, thicker" (p. 74). One is thus taught how to dwell continuously in, and across, an ever-increasing array of environmental contexts or "life-spaces."

From a social, rather than phenomenological, standpoint, Dewey's understanding of education is that it should endow students with the "power to frame purposes," and so enable them to become independent producers of knowledge (p. 67). This knowledge is not an end in itself, though. It is instead directed towards the project of building a democratic social order in which each person's work "makes the lives of others better worth living," and in which individual activity is "uncoerced" in that it does not merely reproduce the interests of a "directive class" (1916/2005, pp. 184-186). The ends of education are not selfish, then, nor are they simply geared towards the cultivation of individual knowledge and productivity. Rather, they are directed towards engendering each person's capacity to positively affect the larger social situation. The knowledge of how to effectively orientate oneself in, and across, diverse contexts is therefore finally equal to the power to positively inform the general human situation. Dewey's phenomenological account of educative space and learning is thus linked with a theory of social change.

\section{Placing Dewey: A History of School Architecture}

It is useful to place Dewey's comments on the traditional "school environment of desks, blackboards, [and] a small schoolyard" (p. 40) in historical perspective, so as to better understand the exact direction of his critique. The key question in this regard is: What elements of traditional schooling led Dewey to believe that the standard educative milieu was divided, in form and in function, from the larger social surround? My answer is necessarily speculative, because Dewey's historical analysis of schooling is mostly broad and theoretical. Nonetheless, Dewey is specific in his recommendations for change, and at the very least, these recommendations can be examined in relation to the structural status quo which existed when Dewey formulated and published his ideas. 
The system of public education which forms the backdrop for Dewey's critique was rooted in the early history of mass education, dating to the late eighteenth and early nineteenth centuries. One influential school model at that time was the monitorial school, first developed in Britain and then adapted by American educationalists (Dudek, 2000, pp. 10-16; Markus, 1993; Rabinowitz, 1974; Seaborne, 1971, pp. 139-236). Plans show that these schools were comparatively large, often housing anywhere from 280 to 1,200 children, depending on the layout (Markus, pp. 56-60). Students were seated in groups, typically ranging from eight to thirty boys, usually in proportion to the overall size of the school. In the Lancasterian model, each group was seated at a long desk facing the schoolmaster's raised platform at the front; while in the National model, they sat on benches arranged in a U-shape, opening either to the headmaster's platform or to the sides of the school. Both arrangements made use of child monitors, ranging from seven to fourteen years in age (depending on whether they were teachers or merely younger assistants), each of whom was responsible for monitoring a group's work. Students were classed or graded by performance, and were seated accordingly. Spatial grouping by age (grade) or by subject area (the subject-specific classroom) was not yet general practice.

The organization of the school relied on a tight co-ordination of movements and tasks, not least because of the sheer complexity of managing large numbers of students within an open space, generally under one or two master teachers. The monitors and their assistants (if there were any) worked in a highly choreographed fashion to deliver the schoolmaster's instructions to the students. The students, in turn, engaged in mechanical exercises such as Biblical recitation and the by-rote acquisition of basic literacy and numeracy. This lock-step, even militaristic, approach ensured that students were kept ontask and were guided through a progressive sequence of lessons in an orderly and disciplined manner. There was at least as much emphasis placed on the learning of moral and intellectual habits as on the substantive content of the lessons. As one eminent observer, Patrick Colquhoun, stated in 1806, the aim of popular education was to provide the poor with "A right bias to their minds, and a sufficient education to enable them to preserve ... the religious and moral instruction they receive" (cited in Markus, p. 55), and that to "go beyond this point would be to confound the ranks of society" by making the poor dissatisfied with their lot in life and potentially rebellious. This was, after all, a revolutionary age.

The lasting influence of monitorial methods is evident in popular schooling through the nineteenth and early-twentieth centuries. This pedagogical strand continued regardless of architectural and curricular modifications which were gradually introduced to accommodate increasingly diverse subject-areas, teaching methods, and student demographics (in terms of class and ethnic composition). Henry Barnard's seminal School Architecture (1854) stresses, for example, that physical education should teach "cleanliness in person, neatness in dress, punctuality, promptitude, and obedience," rather than physical skills per se. This is a moral and intellectual training in line with the monitorial approach (1854/2005, p. 52). David Tyack (1974) traces this kind of overt inculcation of "obedience [and] regularity" well into the 1890's, at which point urban schools had otherwise moved beyond the Lancasterian template by grading according to age, and by placing students in separate classrooms under the eye of a single adult teacher (p. 55).

Carl Kaestle (1983) offers several insights into why the tenor of monitorial education enjoyed such longevity (pp. 67-71). He explains, first, that bureaucrats were attracted to the economic efficiencies promised by a still semi-Lancasterian system that managed a high volume of students with relatively few staff. Bureaucrats also felt that the public system's standardized and uniform curriculum would teach immigrants a common English language, and a common Protestant morality consonant with the Lancasterian values of "hard work and subordination" (p. 71). Finally, most parents supported the idea of childhood discipline because they wanted children to behave deferentially and obediently (see also Reese, 2000, pp. 9-31; and 2005, pp. 10-44).

We can now more clearly delineate why Dewey rebels against the idea of an educative environment which is focused on habit-formation rather than on experientially-driven learning. Dewey is opposed, above all, to the 'monitorial-school' reduction of education to a crudely functionalist 
routine aimed at narrow cognitive and behavioural outcomes. Partly, the problem lies here with the nature of the activities in which students are made to engage: "Practical activities may be intellectually narrow and trivial; they will be so in so far as they are routine, carried on under the dictates of authority, and having in view merely some external result" (1916/2005, p. 160). Yet Dewey, as we have seen, also views the dilemma of traditional education as essentially environmental, insofar as the "relations subsisting between a human being and his natural and social surroundings" (p. 160) are interrupted by the traditional school milieu. For Dewey, school space should open material connections "between what [the student] does to his environment and what it does to him," so that "his acts and the things about him acquire meaning ... [and he] learns to understand both himself and the world of men and things" (p. 160). Otherwise, the school's walls simply enclose the student's world, constricting and thinning (rather than "expanding" and "thickening") the sphere of experience to the point of nearirrelevance.

\section{Building a Future: Contemporary School Architecture and Ecological Design}

The construction of educational facilities has evolved considerably since Dewey's time, at least in a technical sense. We now know empirically, for instance, that air quality, good light, and a quiet and comfortable learning environment are needed for optimal academic performance. Further, these conditions can be presently met within the "limits of existing knowledge, technology, and materials," as long as there is proper funding, design, construction, and maintenance (Schneider, p. 16). Evidence that current design principles are systematically applied in modern construction is seen even by glancing at the sun-lit and generally well-designed school interiors presented in modern guidebooks (e.g., Brubaker, 1998; Crosbie, 2001; Nair \& Fielding, 2005; Perkins, 2001; Yee, 2002). We have evidently reached an apex in the building science underlying school architecture. There does not appear to be anything particularly wrong with the present state of the classroom as a built space engineered to support academic outcomes. It is therefore unsurprising that current studies on educational facilities reveal less anxiety about the quality of school architecture than did the Victorian reformers who struggled to secure funds for even rudimentary school conditions (e.g., National Research Council, 2005; Picus, Marion, Calvo \& Glenn, 2005).

Yet, there is discontent at the margins of the discourse concerning school architecture. One of the most prominent (if moderate) critics of the status quo is the planner-and-architect team, Prakash Nair and Randall Fielding. In The Language of School Design (2005), the authors take square aim at the traditional "classroom-based model of a school," in which time and motion are still segmented in a quasi-monitorial fashion (pp. 17-18). This "cells and bells" paradigm is, according to Nair and Fielding, governed by an industrial-era model of learning that is linear and one-dimensional (p. 19). The authors assert that education should instead be holistic and multi-faceted, and should involve project-based learning and a multidisciplinary approach. Learning spaces should therefore be made more flexible, in order to support dynamic educative processes. One space could be used as a theatre, a cross-curricular presentation forum, and a lecture hall, for example.

The Language of School Design offers a rare illustration of how school design can be aligned with a Deweyean approach to the educative environment. We see, here, how Dewey's sophisticated notion of pedagogic media - e.g., laboratories, gardens, and dramatizations - can be realized in fairly traditional but maximally flexible spaces. We also see attention paid, in Language, to ensuring that "opportunities exist for reproducing the situations of life, and for acquiring and applying information" (p. 96), through spaces that support rigorous teamwork and individual study alike. Finally, Language posits that the educative environment should enhance the delivery of a socially relevant and experientially-driven curriculum, and points the way to designs suited to this purpose. 
There is, however, one theme which should be added to Nair and Fielding's architectural and pedagogical schema: our ecological situation. It is now globally acknowledged that we are entering an age of serious environmental challenges. Accordingly, many national governments are adjusting their economic and industrial policies in an effort to mitigate the long-term ecological impact of human activity. The reasons to do so are becoming pressing. One example should suffice. Even if the yearly flow of carbon dioxide emissions stays at the present rate (and it will likely increase), it is probable that the global average temperature will rise by more than $2^{\circ} \mathrm{C}$ as early as 2035 . With this increase in temperature, we will start to see, among other things: (a) a rising number of people at risk from hunger, particularly in Africa and West Asia; (b) significant changes in water availability; and (c) a steeply accelerating rate of species extinction (which is already at about 100 to 1, 000 times the expected natural extinction rate) (HM Treasury, 2006, p. v; International Union, 2004, p. 1).

Building and maintenance practices can constructively respond to the mounting environmental pressures in several ways. The Toronto District School Board (2006), for one, has implemented various design and maintenance policies which have reduced energy consumption, and thus carbon dioxide emissions:

- Building Automation Systems, which monitor lighting, heating and cooling, were installed in 91 facilities. BAS's have reduced energy consumption per $\mathrm{m}^{2}$ by $15 \%$, relative to other schools on average.

- 167 facilities received lighting retrofits, reducing relative energy consumption by $10 \%$.

- Staff and student energy conservation has reduced relative energy consumption in 44 schools, by an average of $8 \%$.

These steps represent a move in the right direction. Such measures must be a part of any ecologically designed school. Mechanical upgrades or a limited training in conservation go only so far, though, in creating a learning environment that fosters ecological awareness on a deep, perceptual level.

The question of how to transform the built environment into a site that teaches deep ecological awareness is a central concern of ecological design theory. For Sim Van der Ryn and Stuart Cowan (1996), the root problem is that "dumb design has set a complex epistemological trap for us," in that the designed environment generally seals us off from the natural world, while concealing the technological means by which it does so (p. 161). The net result of this obfuscation is that the ecological impact of human activity (waste production, energy consumption, etc.) is often rendered invisible, which means that it is neither acknowledged nor understood by the general public. An environment that is designed "ecologically," however, makes "nature visible" by architecturally expressing the natural world. An extensive use of natural lighting offers one example of this formal integration. The building's interior is linked to the solar cycle, which then subtly attunes occupants to the "flow of climate, season, sun, and shadow" (p. 162).

Van der Ryn and Cowan's ideas about design are remarkably consonant with Dewey's insights into the relationship between learning and the environment. Most importantly, Van der Ryn and Cowan share Dewey's belief that a site should provide a phenomenological orientation towards actual social conditions. In ecological terms, of course, social conditions refer mainly to our relationship with nature; but an ecological commitment to our collective situation is in keeping with Dewey's assertion that education should help individuals make "the lives of others better worth living" (p. 184). Ultimately, ecological design and Dewey's educational theory both connect a phenomenological conception of the built environment with a social program.

The social objectives of Dewey and of ecological design can be merged, finally, within the framework of a school design practice that aims to place learning within an environment that dynamically supports an ecological curriculum. One instance of this kind of design is the Edible Schoolyard project at Martin Luther King, Jr. Middle School, in Berkeley, California (see the school's website at http://www.edibleschoolyard.org/homepage.html). At the core of this project is a large 
kitchen garden that was started by the school in 1994. Students help plant and maintain the garden each year, and attend regular kitchen classes where they learn how to prepare the garden's organic produce. Creative writing sessions are also held in the garden, to encourage students to reflect on their ongoing relationship with it. Science lessons are meanwhile developed in response to various gardening activities, including composting and fruit-tree grafting.

The lessons learned in and around the Edible Schoolyard ultimately extend beyond quantifiable forms of knowledge: they actively link students to the natural world and help make an ecologically sensitive way of dwelling resonate for them. This is a lesson that in the end transcends the monitorial formalism which lurks within the "cells and bells" paradigm, in that it is based not on the cultivation of unthinking habit, but rather on the development of thoughtful action.

\section{References}

Barnard, H. (2005). School architecture; or, contributions to the improvement of schoolhouses in the United States (5 ${ }^{\text {th }}$ ed.). Michigan: University of Michigan University Library. (Original work published 1854).

Brubaker, C. W. (1998). Planning and designing schools. New York: McGraw-Hill.

Crosbie, M. J. (2001). Class architecture. Victoria, Australia: Images Publishing.

Dewey, J. (1997). Experience and education. New York: Simon \& Schuster Inc.. (Original work published 1938).

Dewey, J. (2005). Democracy and education. Stilwel, KS: DigiReads.com Publishing. (Original work published 1916).

Doppelt, Y. (2006). Teachers' and pupils' perceptions of science-technology learning environments [Electronic version]. Learning Environments Research, 9, 163-178.

Dudek, M. (2000). Architecture of schools: The new learning environments. Woburn, MA: Architectural Press.

Freire, P. (2001). The pedagogy of the oppressed (M. B. Ramos, Trans.). New York: Continuum. (Original work published 1970).

Getzels, J. W. (1974). Images of the classroom and visions of the learner. The School Review, 82(4), 527540.

Giddens, A. (1984). The constitution of society: Outline of the theory of structuration. Berkeley: University of California Press.

Heidegger, M. (1971). Building, dwelling, thinking. In M. Heidegger, Poetry, language, thought (A. Hofstadter, Trans.; pp.145-161). New York: Harper \& Row.

HM Treasury (2006). Stern review: The economics of climate change. Retrieved November 24, 2006 from http://www.hm-treasury.gov.uk/media/8AC/F7/Executive_Summary.pdf

International Union for the Conservation of Nature (2004). Species extinction. Retrieved November 24, 2006 from: http://www.iucn.org/themes/ssc/red_list_2004/GSA_book/Red_List_2004_exec_ summary.pdf

Johnson, B. \& Stevens, J. J. (2006). Student achievement and elementary teachers' perception of school climate [Electronic version]. Learning Environments Research, 9, 111-122.

Kaestle, C. F. (1983). Pillars of the republic: Common schools and American society, 1780-1860. New York: Hill \& Wang.

Lackney, J. A. (1996). Quality in school environments: A multiple case study of the diagnosis,design and management of environmental quality in five elementary schools in Baltimore City Public Schools from an action research perspective. Unpublished doctoral dissertation, University of Wisconsin-Milwaukee. (UMI No. 9717142).

Markus, T. A. (1993). Buildings and power: Freedom and control in the origin of modern building types. London: Routledge.

Merleau-Ponty, M. (1981). Phenomenology of perception (C. Smith, Trans.). (Original translation published 1962). 
Nair, P. \& Fielding, R. (2005). The language of school design: Design patterns for 21st century schools. Minneapolis: DesignShare.

National Research Council of the National Academies (2006). Review and assessment of the health and productivity of green schools: An interim report. Retrieved November 23, 2006 from http:// www.nap.edu/catalog/11574.html

Peponis, J. \& Wineman, J. (2002). Spatial structure of environment and behavior. In R. B. Bechtel \& A. Churchman (Eds.), Handbook of environmental psychology (pp. 271-291). New York: John Wiley \& Sons, Inc..

Perkins, B. (2001). Building type basics for elementary and secondary schools. Toronto: John Wiley \& Sons, Inc..

Picus, L. O., Marion, S. F., Calvo, N. \& Glenn, W. J. (2005). Understanding the relationship between student achievement and the quality of educational facilities: Evidence from Wyoming [Electronic version]. Peabody Journal of Education, 80(3), 71-95.

Preziosi, D. (1979). The semiotics of the built environment: An introduction to architectonic analysis. Bloomington: Indiana University Press.

Rabinowitz, R. (1974). The crisis of the classroom: Architecture and education [Electronic version]. History of Education Quarterly, 14(1), 115-123.

Reese, W. J. (2000). Public schools and the elusive search for the common good. In L. Cuban \& D. Shipps (Eds.), Reconstructing the common good in education (pp. 13-31). Stanford, CA: Stanford University Press.

Reese, W. J. (2005). America's public schools: From the common school to "No Child Left Behind." Baltimore: Johns Hopkins University Press.

Robinson, M. (2003). Place-making: The notion of centre. A Typological investigation of means and meanings. In S. Menin (Ed.), Constructing place: Mind and matter (pp. 143-153). London: Routledge.

Rossi, A. (1984). The architecture of the city. Cambridge, MA: The MIT Press.

Schneider, M.(2002). Do school facilities affect academic outcomes? National Clearinghouse for Educational Facilities. Retrieved November 23, 2006, from http://www.edfacilities.org/pubs/outcomes.pdf

Seaborne, M. (1971). The English school: Its architecture and organization, 1370-1870. Toronto: University of Toronto Press.

Tanner, C. K. (2000). The influence of school architecture on academic achievement [Electronic version]. Journal of Educational Administration, 34(4), 309-330.

Toronto District School Board (2006). Energy management program review. Toronto: Toronto District School Board.

Tyack, D. (1974). The one best system: A bistory of American urban education. Cambridge, MA: Harvard University Press.

Van der Ryn, S. \& Cowan, S. (1996). Ecological design. Washington: Island Press.

Yee, R. (Ed.). (2002). Educational environments. New York: Visual Reference Publications, Inc.

\section{About the Author}

Neil Gislason is a PhD student in Adult Education and Counselling Psychology at the Ontario Institute for Studies in Education of the University of Toronto. His research interests include school architecture, the history of education, and pedagogy. He is the current editor of the Centre for Artsinformed Research newsletter, at OISE/UT. 